\title{
STUDI SUSUNAN LAPISAN SERAT PENGUAT YANG IDEAL UNTUK "BIDUAK" PERAHU TRADISIONAL MINANGKABAU
}

\author{
Rahmat Azis Nabawi ${ }^{1)^{*}}$, Syahril ${ }^{2)}$, Aprizal Saputra ${ }^{3)}$, Salmat $^{4)}$, Arya Zulhendrik ${ }^{5)}$ \\ Jurusan Teknik Mesin, Universitas Negeri Padang, Jalan Prof. Dr. Hamka Air Tawar, Padang, Indonesia. \\ raazna@ft.unp.ac.id *; syahril@ft.unp.ac.id; aprizalsaputra@student.unp.ac.id; salmat1710@gmail.com; \\ aryazulhendrik@gmail.com
}

\section{ABSTRAK}

Biduak merupakan perahu dari budaya Minangkabau yang umumnya banyak digunakan sebagai alat transportasi di danau. Biduak dibuat dari kayu gelondongan yang dibentuk hingga menjadi sebuah perahu yang mempunyai ciri khas. Penggunaan kayu sebagai bahan baku utama pembuatan Biduak tidak bersahabat dengan lingkungan dapat menyebabkan bencana banjir, longsor pengurangan produksi oksigen dan pemanasan global. Penelitian ini mengkaji lapisan serat pada fiber yang ideal dalam menahan tekanan yang dialami dengan mempertimbangkan berat biduak itu sendiri. Untuk mengungkapkan pressure yang dialami oleh lambung perahu ketika berlayar dilakukan dengan the Computer Fluid Dynamic (CFD). Pembuatan specimen fiber dilakukan dengan metode hand-layout, dengan variasi lapisan serat. Serat penguat menggunakan jenis E-glass dengan tipe Chop Strand Mat 300 dan Woven Roving 600. Matrik menggunakan Unsaturated Polyester Resin BQTN 157-EX. Pengukuran kekuatan tarik dilakukan dengan menggunakan Universal Testing Machine. Hasil simulasi CFD mengungkapkan bahwa tekanan terbesar yang dialami biduak ketika berlayar adalah sebesar 10.4 MPa pada kecepatan $1 \mathrm{~m} / \mathrm{s}$. Hasil pengujian tarik pada setiap spesimen menunjukan bahwa semuanya memiliki kekuatan tarik yang lebih besar dari tekanan yang diterima oleh lambung biduak ketika berlayar. Berdasarkan pertimbangan berat, spesimen 1 yang paling ideal digunakan untuk pembuatan lambung biduak. Hasil penelitian ini diharapkan dapat menjadi dasar dalam penelitian serat fiber yang digunakan untuk perahu tradisonal, seperti pencarian serat alam untuk perahu fiber yang mampu menahan pressure ketika pelaru berlayar.

Kata kunci: CFD, Perahu tradisional, Perahu fiber, Uji Tarik, biduak

\section{ABSTRACT}

Biduak is a boat from Minangkabau culture which is generally used as a means of transportation on the lake. Biduak is made of logs that are shaped to become a boat that has a characteristic. The use of wood as the main raw material for making Biduak is not friendly to the environment and can cause floods, landslides, reduced oxygen production and global warming. This study examines the fiber layer on the ideal fiber to withstand the stress experienced by considering the weight of the pawn itself. To reveal the pressure experienced by the hull of the boat when sailing is done with the Computer Fluid Dynamic (CFD). Manufacture of fiber specimens is carried out by the hand-lay-up method, with variations in fiber layers. The reinforcing fiber uses E-glass type with Chop Strand Mat 300 and Woven Roving 600 types. The matrix uses Unsaturated Polyester Resin BQTN 157-EX. Tensile strength measurements were carried out using the Universal Testing Machine. The results of the CFD simulation revealed that the greatest pressure experienced by the Big Dipper when sailing was $10.4 \mathrm{MPa}$ at a speed of $1 \mathrm{~m} / \mathrm{s}$. The results of the tensile test on each specimen show that all of them have a tensile strength greater than the pressure received by the hull of the pawn when sailing. Based on weight considerations, specimen 1 is the most ideal used for the manufacture of hulls. The results of this study are expected to be the basis for research on fibers used for traditional boats, such as the search for natural fibers for fiber boats that are able to withstand pressure when the sailor sails.

Keywords: CFD, Traditional Boat, boat fiber, tensile strength, biduak

Diunggah November 2021, direvisi: Desember 2021, diterima: Desember 2021, dipublikasi: 31Desember 2021 Copyright (c) 2021 Rahmat Azis Nabawi, Syahril, Aprizal Saputra, Salmat, Arya Zulhendrik

This is an open access article under the CC-BY license 


\section{PENDAHULUAN}

Biduak merupakan perahu tradisional dari budaya Minangkabau. Biduak umumnya digunakan untuk mencari ikan di danau, sungai atau diperairan tenang. Biduak dibuat dari kayu gelondongan yang dikeruk dan dibentuk hingga menjadi perahu (Gambar 1). Pembuatan biduak dengan teknik ini sangat boros terhadap bahan baku kayu dan tidak bersahabat dengan lingkungan. Penebangan kayu di hutan dapat menyebabkan bencana banjir, longsor, pengurangan pohon untuk produksi oksigen dan berdampak kepada peningkatan pemanasan global. Defortation berkaitan erat dengan peningkatan $\mathrm{CO}_{2}$ atmosfer, parubahan energi dipermukaan dan keseimbangan masa yang dapat menyebabkan perubaham iklim lokal (Longobardi et al., 2016), dan ini merupakan pendorong utama dalam perubahan iklim dunia (Prevedello et al., 2019).

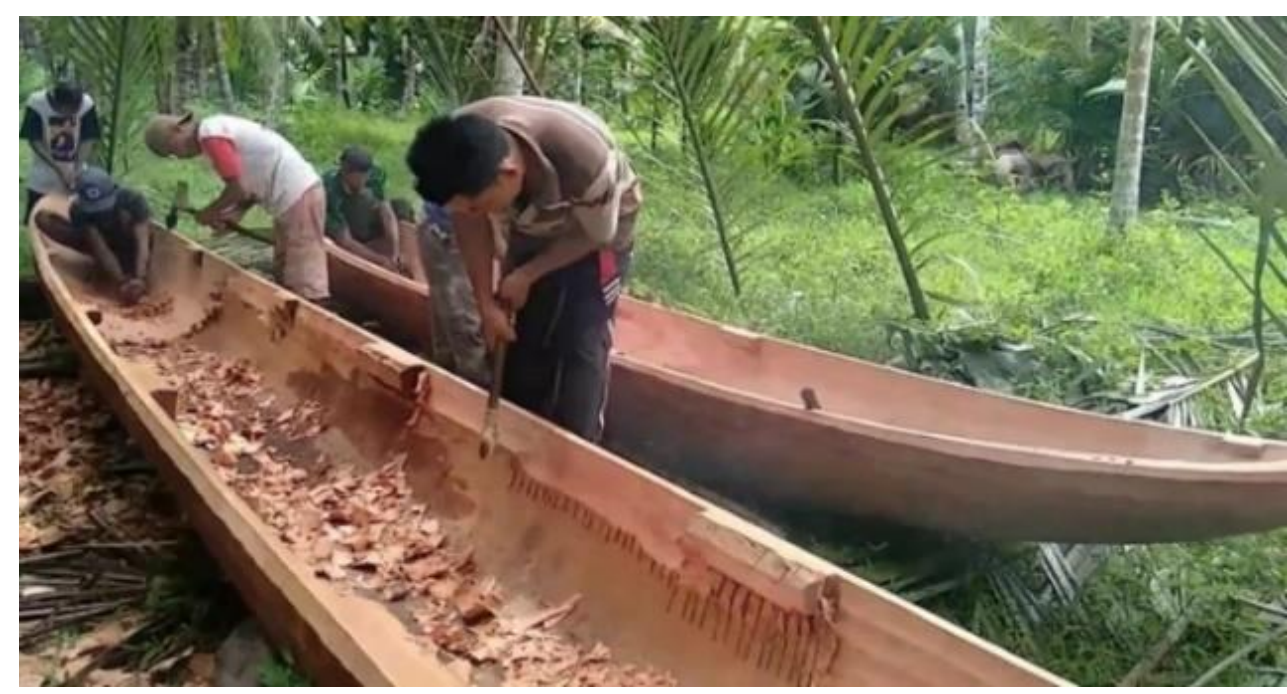

Gambar 1. Proses Pembuatan Biduak

Bahan baku pembuatan biduak menggunakan baja membutuh peralatan yang berteknologi tinggi seperti mesin tekuk untuk pembentukan lengkungan lambung dan metode penyambungan dengan teknik pengelasan yang harus memiliki kualitas mutu baik. Hal ini tentu akan menyulitkan masyarakat nelayan untuk bisa membuat biduak secara mandiri jika menggunakan bahan baja. Alternatif bahan baku yang dapat digunakan untuk pembuatan biduak yang mudah diproduksi secara mandiri adalah menggunakan fiberglass. Pembuatan biduak dari bahan baku fiberglass dapat dilakukan dengan metode hand lay-up (Catur \& Salman, 2020). Pembuatan biduak dengan metode hand lay-up dapat dilakukan menggunakan peralatan sederhana yang mudah didapatkan dan metode pekerjaan yang mudah dilakukan.

Selama berlayar lambuang biduak akan menerima tekanan dari air. Biduak tidak menggunakan gading dan galar, oleh karena itu perlu diketahui berapa tekanan yang bekerja pada lambung ketika berlayar. Lambung perahu fiberglass umumnya dibuat dengan bentuk struktur laminate composite atau dibuat dengan lebih dari satu lapisan serat pegnuat (layer). Jenis serat penguat yang umum digunakan adalah Chopped Glass Fiber (CSM 300) dan Woven Rovin 600 (WR 600). Pengikat serat menggunakan Resin. Semakin banyak lapisan penguat makan semakin kuat juga lambung biduak, namun tentu akan semakin besar bobotnya. Berat biduak akan mempengaruhi kepada tenaga yang dibutuhkan untuk mendayungnya, semakin besar berat biduak maka semakin besar tenaga yang dibutuhkan untuk mendayungnya. Penelitian ini mengkaji komposisi lapisan serat penguat untuk pembuatan lambung biduak fiberglass yang ideal berdasarkan kemampuan dalam menahan tekanan dan mempertimbangkan berat biduak itu sendiri. 


\section{METODE}

\section{Prosedur Penelitian}

Konseptual penelitian disajikan pada gambar 2. Pengungkapan tekanan yang dialami oleh lambung biduak dilakukan dengan metode Computer Fluid Dynamic (CFD) menggunakan software Solidworks 2021-2022 research license. Selanjutnya mengungkapkan kekuatan dari fiberglass dengan bentuk struktur laminate composite dilakukan dengan pengujian tarik menggunakan Universal Testing Machine. Dimensi biduak disajikan pada tabel 1 dan line plan disajikan pada gambar 3. Dimensi dan bentuk lambung mengacu kepada biduak yang umum digunakan oleh nelayan yang ada di Sumatera Barat.

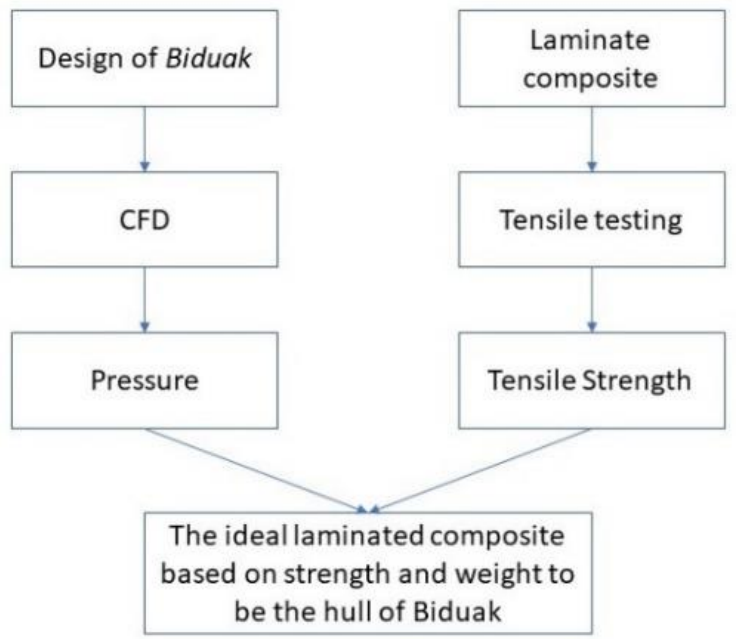

Gambar 2. Prosedur penelitian

Tabel 1. Spesifikasi Biduak

\begin{tabular}{llllc}
\hline \multicolumn{1}{c}{ Lambung } & \multicolumn{3}{c}{ Ukuran Utama } \\
\hline Tipe Lambung Kapal & $:$ U Hulls & Length of All & $: 4$ & $\mathrm{~m}$ \\
Tipe Haluan & $:$ Raked Bow & Length Water Line & $: 3.5$ & $\mathrm{~m}$ \\
Kapasitas & $:$ 200 Kg & Beam & $: 0.3$ & $\mathrm{~m}$ \\
Bahan & $:$ Fiberglass & Breadth at The Waterline & $: 0.25$ & $\mathrm{~m}$ \\
& & Depth & $: 0.30 \mathrm{~m}$ \\
& Draugth & $: 0.15 \mathrm{~m}$ \\
\hline
\end{tabular}

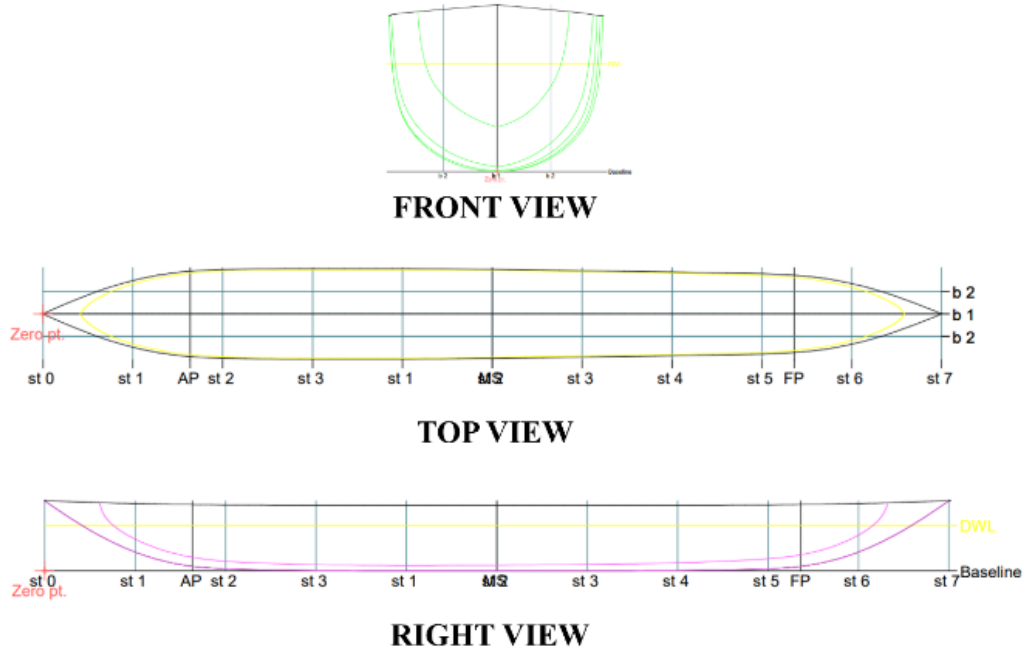

Gambar 3. Line plan Biduak 


\section{Computer Fluid Dynamic (CFD)}

Untuk mengungkapkan tekanan yang dialami biduak ketika berlayar dilakukan dengan metode CFD. Melalui pengunaan teknologi komputer, tekanan atau tahanan yang dialami oleh kapal ketika berlayar dapat diukur secara akurat (Abhiroop et al., 2018) (Syahril \& Nabawi, 2019) (Nabawi et al., 2020). Simulasi dilakukan dengan kecepatan $0.1 \mathrm{~m} / \mathrm{s}, 0.15 \mathrm{~m} / \mathrm{s}, 0.2 \mathrm{~m} / \mathrm{s}$, $0.25 \mathrm{~m} / \mathrm{s}$ dan $0.3 \mathrm{~m} / \mathrm{s}$, kecepatan ini berdasarkan kecepatan terendah hingga tertinggi yang dilakukan oleh nelayan. Computational domain mengacu kepada standar yang telah ditetapkan oleh International Towing Test Conference (ITTC, 2011).

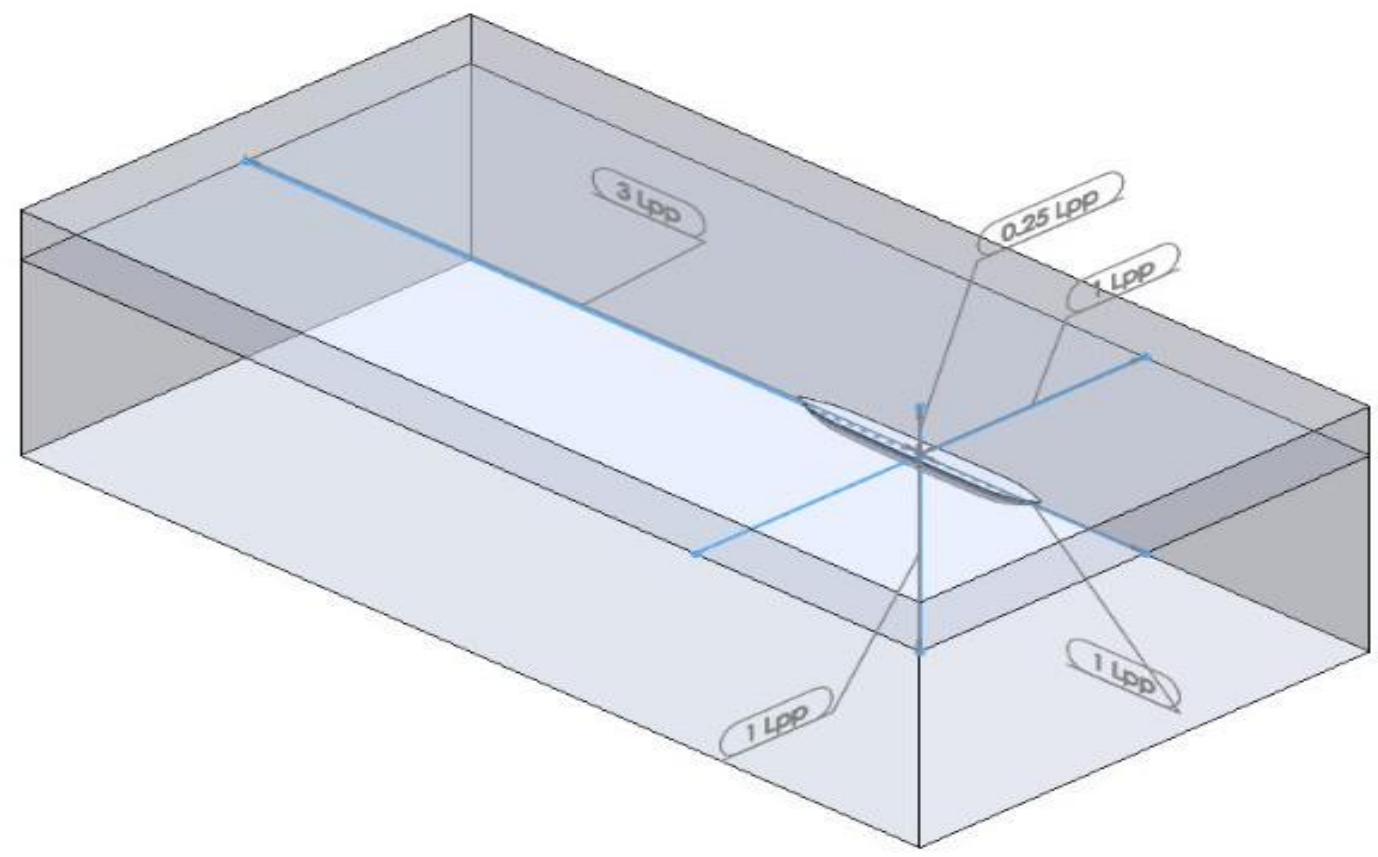

Gambar 4. Computational domain

Verfikasi data hasil simulasi CFD dilakukan dengan mengecek konvergensi, hasil yang akurat ditandai dengan residual atau selisih hasil perhitungan antara iterasi pertama dan setelahnya harus diperoleh sekecil-kecilnya hingga mendekati nilai nol (normalized scale 0 1) (Nabawi et al., 2021). Akurasi dan optimalnya hasil simulasi pada penelitian ini ditunjukan pada setiap goal yang telah ditetapkan yang ditandai dengan "Achieved $(\mathrm{IT}=\ldots)$ ", hasil ini didapatkan pada setiap selesainya simulasi CFD disetiap model kapal. Validasi data hasil simulasi dilakukan dengan mengatur mesh yang digunakan. Berdasarkan literatur semakin besar jumlah mesh, maka hasil semulasi akan semakin berkualitas. Berdasarkan hasil penelitian, hasil simulasi CFD yang kompetibel dengan hasil uji eksperimen menggunakan towing test adalah dengan ukuran mesh yang kecil dan jumlah cell yang banyak (Celik et al., 2020). Simulasi CFD pada biduak ini, total cell yang digunakan adalah satu juta, area yang dekat dengan lambung disempurnakan dan pada area yang dekat dengan dinding domain menggunakan grid yang lebih besar untuk menghindari terjadinya refleksi gelombang (Gambar $5)$. 


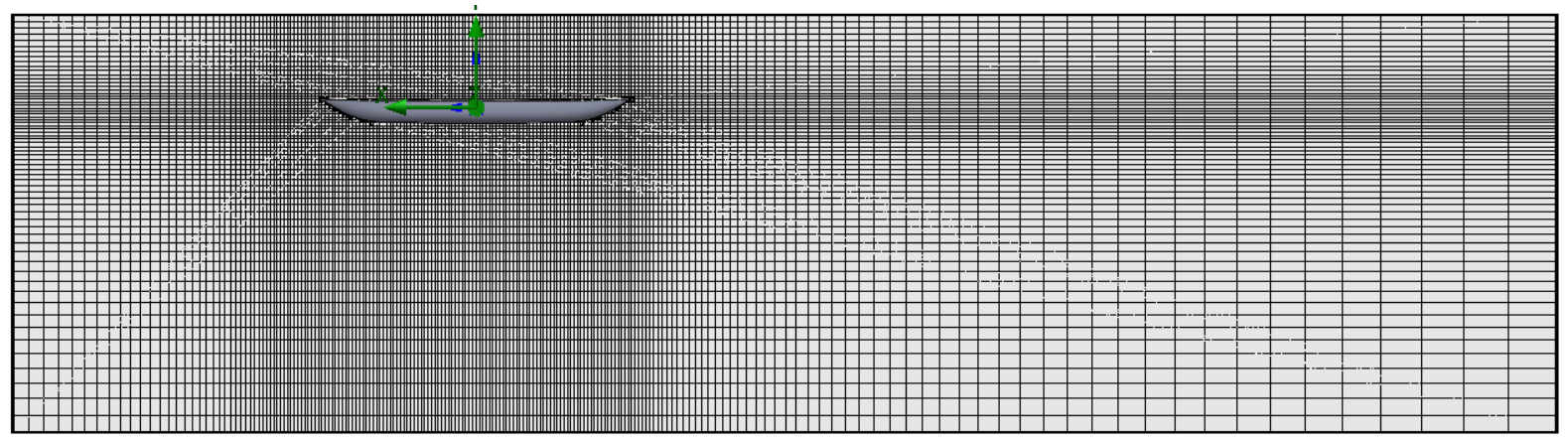

Gambar 5. Mesh yang digunakan pada penelitian ini

\section{Spesimen Fiberglass Lambung}

Penetapan komposisi lapisan serat penguat untuk lambung biduak berdasarkan tekanan yang dialami ketika berlayar dan mempertimbangkan berat biduak itu sendiri. Untuk mengungkapkan susunan lapisan yang ringan namun mampu menahan tekanan, maka dilakukan pengujian kekuatan tarik. Jenis serat penguat yang umum digunakan adalah Chopped Glass Fiber (CSM 300) dan Woven Rovin 600 (WR 600). Pengikat serat menggunakan Resin BQTN 157 Yukalac. Gambar 6 menunjukan variasi lapisan serat penguat (laminate composite) yang umumnya digunakan untuk pembuatan perahu, boat atau kapal fiber. Spesimen untuk pengujian tarik menggunakan standar ASTM D3039 (gambar 7). Pengujian tarik dilakukan dengan menggunakan Universal Testing Machine dengan kapasitas $50 \mathrm{KN}$.

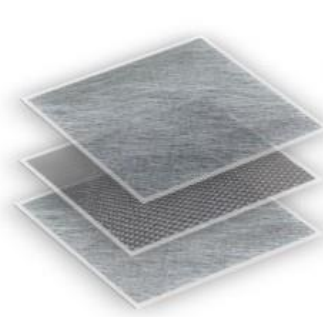

Specimen 1

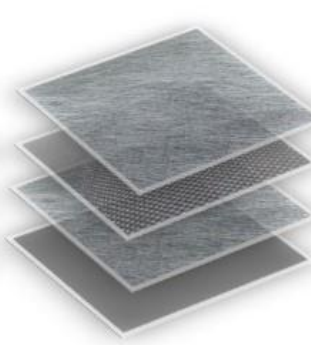

Specimen 2

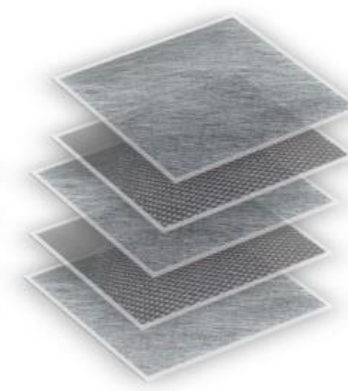

Specimen 3

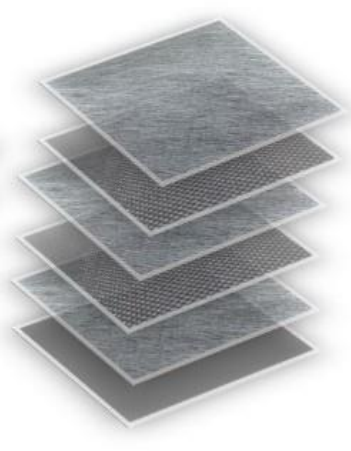

Specimen 4

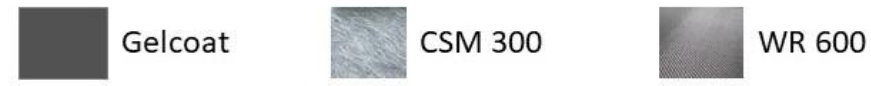

Gambar 6. Variasi lapisan serat penguat untuk lambung biduak

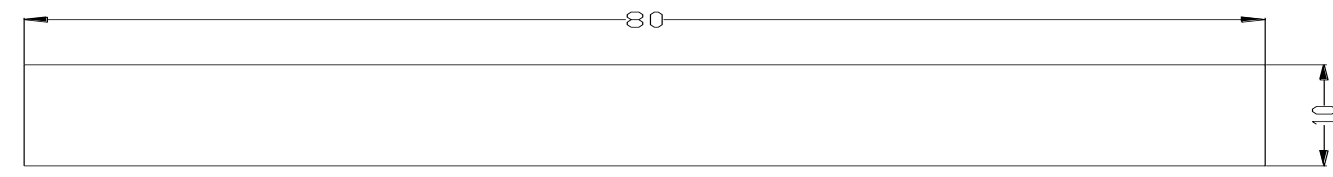

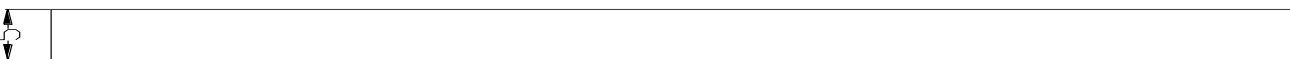

Gambar 7. Dimensi \& Geometri spesimen ASTM D3039 tanpa Tab 


\section{HASIL DAN PEMBAHASAN \\ Tahanan dan tekanan}

Tahanan yang dialami kapal ketika biduak berlayar ditunjukan pada gambar 8 . Berdasarkan hasil simulasi CFD didapatkan bahwa tahanan tertinggi yang dialami biduak adalah pada kecepatan $0.3 \mathrm{~m} / \mathrm{s}$ dengan tahanan yang dialami sebesar $2.12 \mathrm{~N}$. Hasil simulasi menunjukan bahwa semakin cepat biduak melaju maka semakin besar tahanan yang dialami.

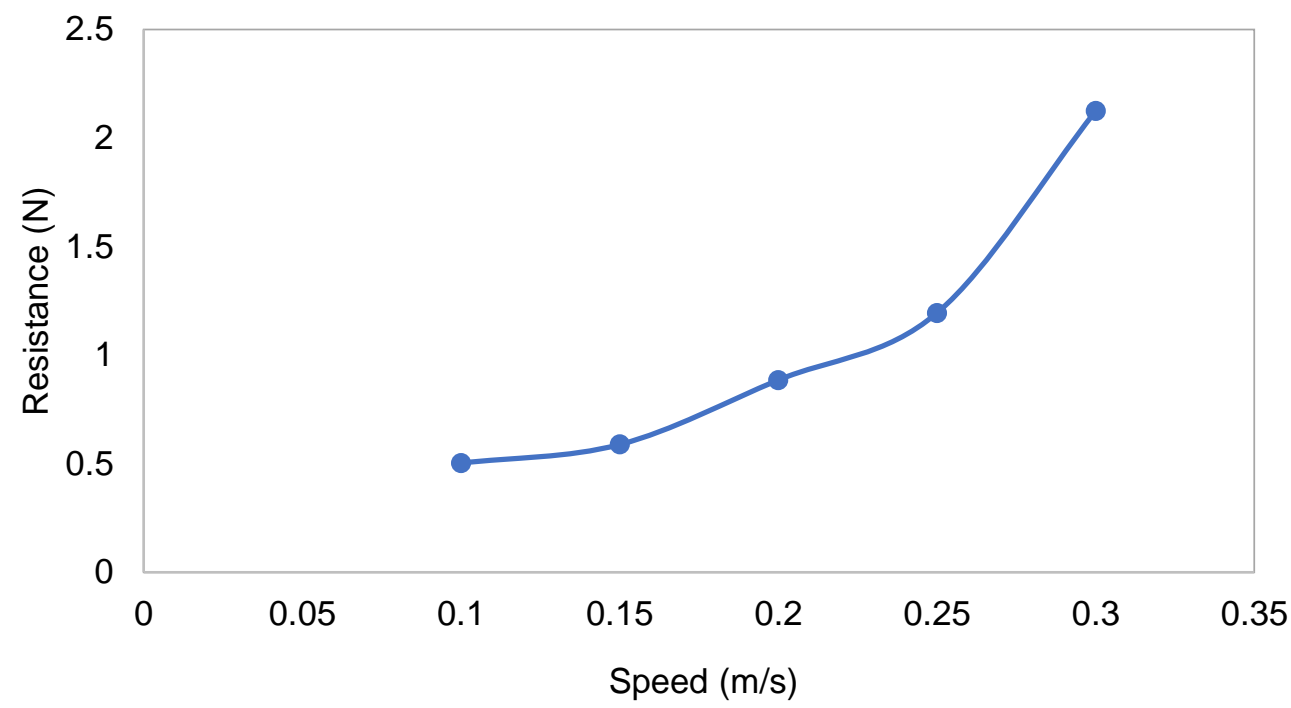

Gambar 8. Tahanan yang dialami biduak pada setiap kecepatan

Besaran tahanan yang dialami oleh lambung biduak pada masing-masing kecepatan ditunjukan pada gambar 9. Berdasarkan hasil simulasi CFD, tekanan yang paling basar dialami oleh biduak adalah ada kecepatan $0.1 \mathrm{~m} / \mathrm{s}$, sebesar $10.4 \mathrm{MPa}$. Tekanan yang terendah pada kecepatan $0.15 \mathrm{~m} / \mathrm{s}$, sebesar $10.29 \mathrm{MPa}$. Bagian yang mengalami tekanan paling besar diseluruh kecepatan adalah pada bagian bawah lambung, seperti yang ditunjukan pada gambar 10. Oleh sebab itu pada lambung bagian bawah biduak harus dibuat lebih kuat.

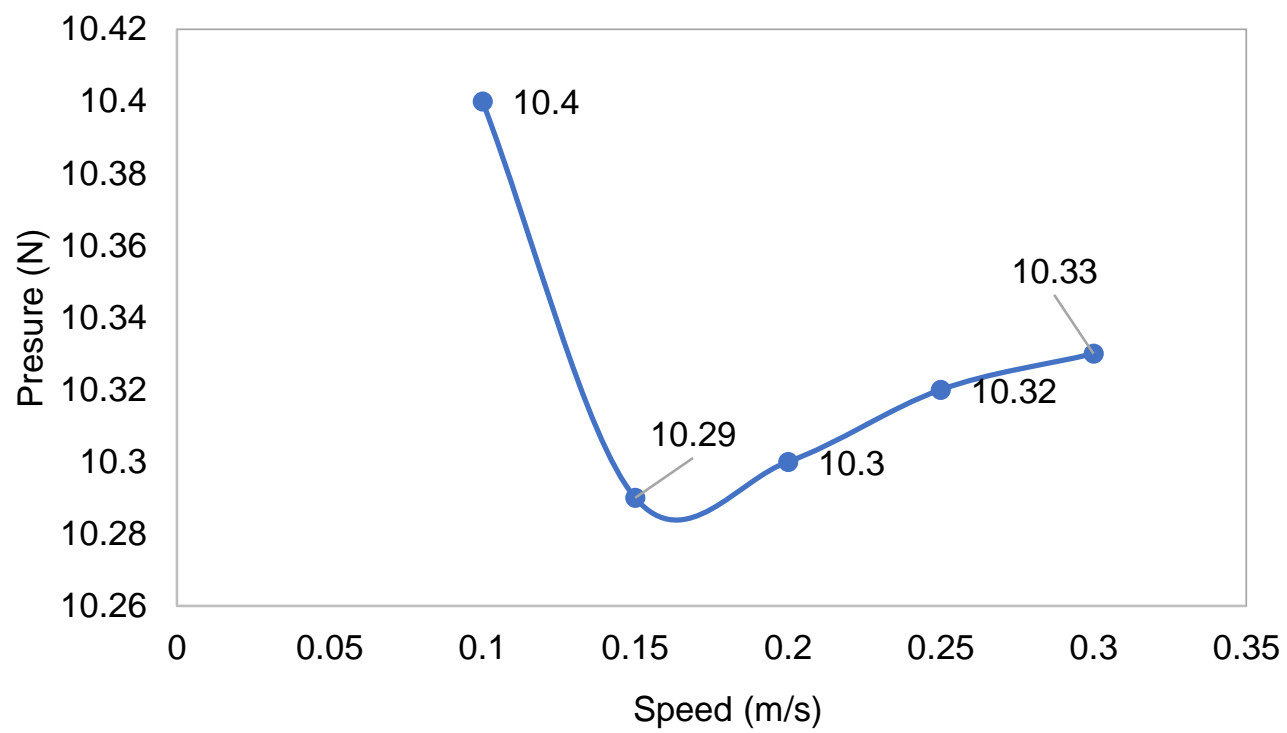

Gambar 9. Tekanan yang dialami lambung biduak persatuan kecepatan 


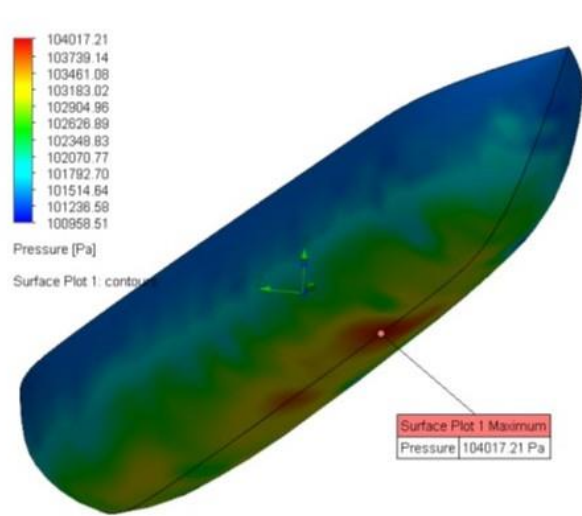

$0,1 \mathrm{~m} / \mathrm{s}$

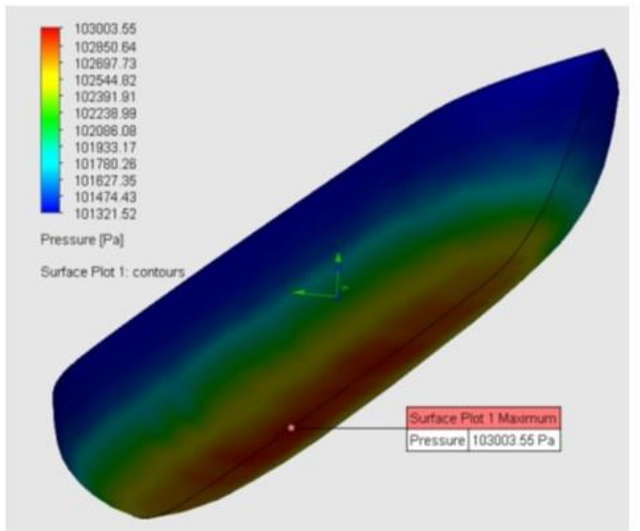

$0,2 \mathrm{~m} / \mathrm{s}$
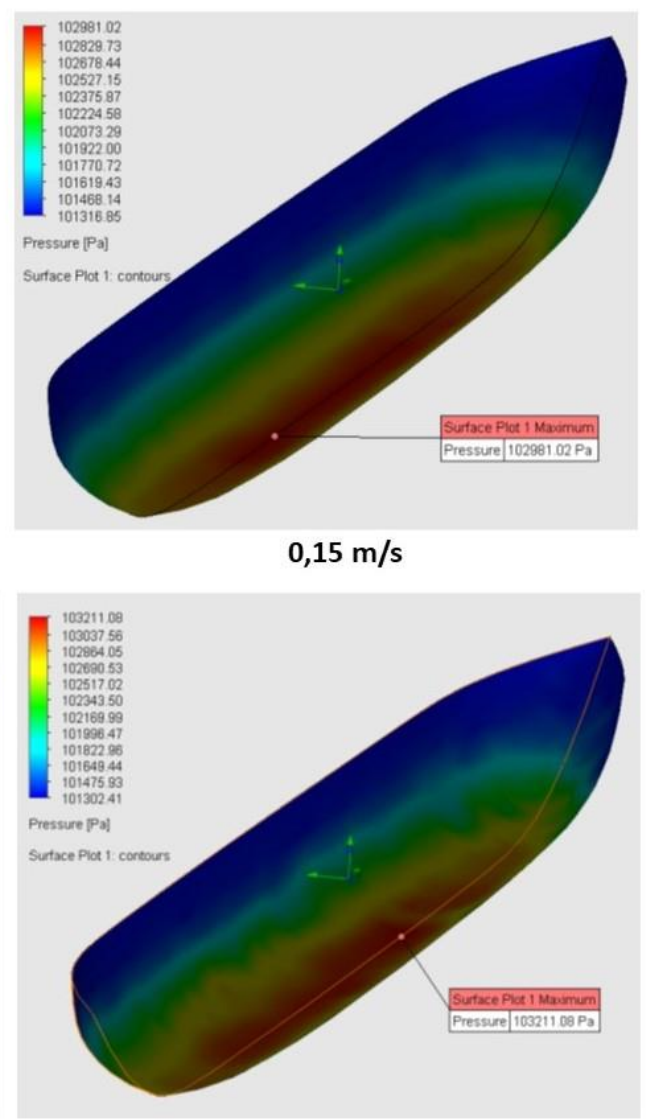

$0,25 \mathrm{~m} / \mathrm{s}$

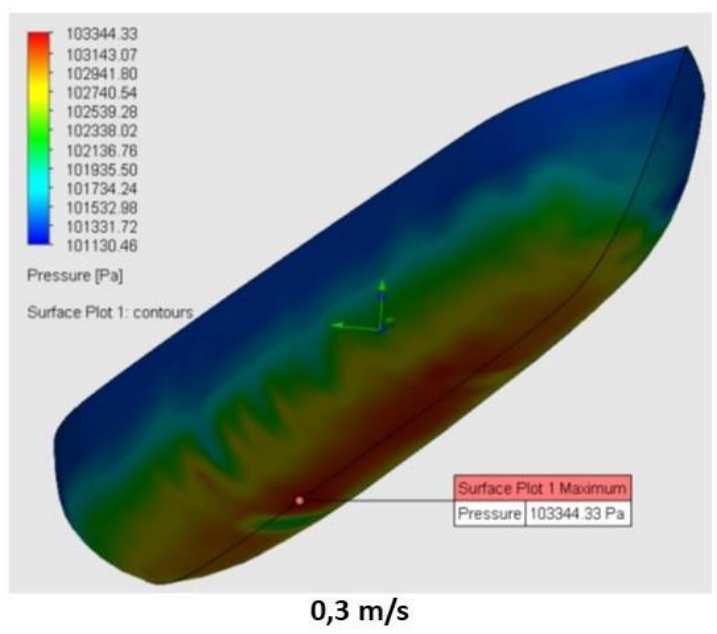

Gambar 10. Capture tekanan yang dialami oleh biduak pada setiap kecepatan.

\section{Susunan lapisan serat penguat untuk lambung biduak}

Hasil perbandingan kekuatan tarik dari setiap spesimen ditunjukan pada tabel 2. Kekutan tarik terendah adalah pada spesimen 1 sebesar 30.68 Mpa dan yang paling besar adalah pada spesimen 4 sebesar $60.09 \mathrm{Mpa}$. Pada spesimen 1 dan spesimen 2, susunan serat penguat terdiri dari CSM 300, WR 600 dan CSM 300, namun pada spesimen 2 lapisan pertama menggunakan gelcoat. Spesimen 1 memiliki kekuatan tarik sebesar $30.68 \mathrm{Mpa}$ dan pada spesiment 2 memiliki kekuatan tarik sebesar 34.64 MPa. Kekuatan tarik spesimen 2 dengan adanya gelcoat lebih besar $3.96 \mathrm{MPa}$ dari pada spesiment 1. Pada spesimen 3 dan spesimen 4 susunan serat penguat adalah CSM 300, WR 600, CSM 300, WR 600 dan CSM 300, namun pada spesiment 4 lapisan 
pertama menggunakan gelcoat. Kekuatan tarik spesimen 3 adalah $56.47 \mathrm{MPa}$ dan spesimen 4 $60.09 \mathrm{MPa}$. Penambahan kekuatan tarik pada spesimen 4 dengan adanya lapisan gelcoat sebesar 3.62 MPa.

Tabel 2. Kekuatan Tarik dan Berat masing-masing spesimen

\begin{tabular}{llll}
\hline \multicolumn{1}{c}{ Spesimen } & \multicolumn{1}{c}{ Kekuatan Tarik (MPa) } & \multicolumn{1}{c}{ Berat Spesimen (g) } \\
\hline Spesimen 1 & 30.68 & 7 & \\
Spesimen 2 & 34.64 & 9 & \\
Spesimen 3 & 56.47 & 11 & \\
Spesimen 4 & 60.09 & 13 & \\
\hline
\end{tabular}

\section{SIMPULAN}

Berdasarkan hasil simulasi CFD, pada masing-masing kecepatan ditemukan bahwa tekanan yang dialami oleh biduak berbeda-beda. Tekanan terbesar dialami lambung biduak adalah pada kecepatan $1 \mathrm{~m} / \mathrm{s}$ sebesar $10.4 \mathrm{MPa}$. Dari kecepatan biduak terendah hingga tertinggi rentang tekanan yang dialami lambung biduak adalah $10.29 \mathrm{MPa}-10.4 \mathrm{MPa}$. Hasil pengujian tarik menunjukan bahwa kekuatan tarik semua spesimen lebih besar dari tekanan yang bekerja pada lambung ketika berlayar, namun berdasarkan berat yang paling rendah adalah spesimen 1 . Berdasarkan hasil penelitian yang telah dilakukan direkomendasikan untuk pembuatan biduak cukup menggunakan lapisan serat penguat seperti spesimen 1. Bobot dari biduak akan mepengaruhi kepada daya muat dan tenaga yang dibutuhkan untuk mendayungnya. Semakin besar bobot biduak tentu daya muatnya akan semakin kecil. Pada penelitian berikutnya perlu juga mengkaji tentang stabilitas biduak fiber yang lebih ringan ini dari pada biduak dari bahan kayu.

\section{DAFTAR PUSTAKA}

Abhiroop, K., Saidas, V., \& Shameem, B. . (2018). A review on the advancement of CFD technique in ship hydrodynamics. 8(12), 2250-3005.

Catur, A. D., \& Salman, S. (2020). Manufacture of Composire Sandwidch Fishing Boat With The Hand Lay Up Technique. 15(2), 65-76.

Celik, C., Danisman, D. B., Kaklis, P., \& Khan, S. (2020). An investigation into the effect of the hull vane on the ship resistance in openfoam. Sustainable Development and Innovations in Marine Technologies - Proceedings of the 18th International Congress of the International Maritime Association of the Mediterranean, IMAM 2019, 136-141. https://doi.org/10.1201/9780367810085-17

ITTC. (2011). Report 7.5-03-02-03: Practical Guidelines for Ship CFD Applications. ITTC Recommended Procedures and Guidelines, 1-18.

Longobardi, P., Montenegro, A., Beltrami, H., \& Eby, M. (2016). Deforestation induced climate change: Effects of spatial scale. PLoS ONE, 11(4). https://doi.org/10.1371/journal.pone.0153357

Nabawi, R. A., Syahril, \& Primawati. (2021). Study Reduction of Resistance on The Flat Hull Ship of The Semi-Trimaran Model: Hull Vane Vs Stern Foil. CFD Letters, 13(12), 32- 
Nabawi, R. A., Syahril, S., \& Salmat, S. (2020). Stability Study of Flat Hull Ship for Fishing Tourism. Teknomekanik, 3(2), 80-85. https://doi.org/10.24036/teknomekanik.v3i2.9272

Prevedello, J. A., Winck, G. R., Weber, M. M., Nichols, E., \& Sinervo, B. (2019). Impacts of forestation and deforestation on local temperature across the globe. PLOS ONE, 14(3), 118. https://doi.org/10.1371/journal.pone.0213368

Syahril, \& Nabawi, R. A. (2019). Numerical investigation of the effect on four bow designs flat hull ship. International Journal of GEOMATE, 17(62), 231-236. https://doi.org/10.21660/2019.62.95333 